${ }^{4}$ Werner B. Fertility trends in different social classes: 1970 to 1983. Population Trends 1985;41:5-13.

5 Smith A. Observations on the determinants of human multiple births. Supplement to the Annual Report of the Registrar General for Scotland. 1964. (Number 110.) Edinburgh: HMSO, 1966:70-82.

Correspondence to Dr M Murphy, Department of Community Medicine and General Practice, Radcliffe Infirmary, Oxford OX2 $6 \mathrm{HE}$.

Accepted 18 July 1988

\title{
Resident parents and shorter hospital stay
}

\author{
M R H TAYLOR AND P O'CONNOR* \\ National Children's Hospital and ${ }^{*}$ Department of Paediatrics, Trinity College, Dublin
}

\begin{abstract}
SUMmARY A total of 586 admissions for 12 medical conditions were reviewed. The stay of children accompanied by a resident parent was $31 \%$ shorter than those whose parents were not resident. Resident parents benefit the emotional well being of the child and increase hospital efficiency; accommodation for parents should therefore be an integral part of a unit admitting children.
\end{abstract}

The number of resident parents in the National Children's Hospital has risen from nine (accompanying $0.4 \%$ of admissions) in 1970 to 1527 (accompanying $38.9 \%$ of admissions) in 1987. It is generally recognised that children in hospital benefit from the presence of a living in parent. ${ }^{12}$ The main emphasis has been on the benefit of the child's emotional well being. The importance of the parent in dealing with the adult world of the hospital on the child's behalf has been stressed. ${ }^{2}$ In addition to these emotional benefits we noted a tendency for children with resident parents to have shorter hospital stays than those whose parents did not live in, but we were unable to find any published record of this observation. We studied the duration of stay of children admitted for a range of medical conditions with and without their parents.

\section{Patients and methods}

All admissions to the National Childrens' Hospital for medical conditions over an eight month period were reviewed. Twelve diagnostic categories were selected in which it seemed possible that a parent's ability to manage a convalescent child would result in a reduction in the hospital stay. Only the primary diagnosis was used in selecting patients. The diagnoses used are given in table 1 . As a very prolonged stay might discourage parents from living in, children with a stay of more than 14 days were excluded. This reduced the study population by 19 . The unpaired $t$ test and the $\chi^{2}$ test were used for statistical analysis. As the duration of stay data were skewed a log transformation was used in the analysis.

Resident parents lived in the hospital. Parents who spent the day in hospital but slept elsewhere were not regarded as resident.

\section{ELIGIBILITY GROUPS}

The eligibility group gives a measure of the affluence of the family. For the purpose of determining eligibility to health services in the Republic of Ireland patients are assessed according to their family income and social circumstances. The criteria used at the time of this study can be summarised as follows:

Group 1: Unemployed breadwinner; single mother; family income below $£ 90.50$ per week (with a $£ 10$ allowance for each child under 16 years old). Other social and economic factors are also taken into account.

Group 2: Family income less than $£ 11000$ per annum.

Group 3: Those not falling into groups 1 or 2 . Almost all patients in this group were covered by a medical insurance scheme.

\section{Results}

A total of 586 admissions were studied; 136 patients were accompanied by a resident parent and had a mean duration of stay of 2.88 days. On 450 admissions a resident parent did not accompany the child and the mean duration of stay was $4 \cdot 16$ days. The difference between these groups was highly significant (table 1). Children of affluent familes (group 3) were more likely to be accompanied by a 
resident parent $\left(\chi^{2}=24 \cdot 2, d f=2, p<0.0005\right)$. In all eligibility groups children with resident parents had a shorter duration of stay than those without. This difference was only significant for group 2 (ratio of geometric means $=1.59,95 \%$ confidence interval 1.29 to $1.96, \mathrm{df}=328, t=4.34, \mathrm{p}<0.001$ ) and 3 (ratio of geometric means $=1 \cdot 35,95 \%$ confidence interval 1.04 to $1.75, \mathrm{df}=167, t=2.28, \mathrm{p}<0.025)$ (table 2).

The mean stay for all children in group 3 was significantly shorter than for group 1 (ratio of geometric means $1 \cdot 30,95 \%$ confidence interval 1.07 to $1.59, t=2.67, \mathrm{df}=\mathrm{p}<0.01$ ) or group 2 (ratio of geometric means $1 \cdot 26,95 \%$ confidence interval $1 \cdot 10$ to $1.45, t=3.29, \mathrm{df}=473, \mathrm{p}<0.005)$. The difference in mean stay between groups 1 and 2 was not significant.

Children in the 3 to 5 year age group had the highest percentage of resident parents $(40 \cdot 5 \%)$ (table 2). This was significantly more than both the younger $\left(\chi^{2}=6 \cdot 3, \mathrm{df}=1, \mathrm{p}<0 \cdot 02\right.$, diff $=0 \cdot 15,95 \%$

Table 1 Mean duration of stay for patients with and without a resident parent in each diagnostic group

\begin{tabular}{|c|c|c|c|c|c|c|c|c|c|c|}
\hline \multirow{2}{*}{$\begin{array}{l}\text { Diagnostic } \\
\text { group }\end{array}$} & \multirow{2}{*}{$\begin{array}{l}\text { Mean }(S D) \\
\text { days stay } \\
\text { without } \\
\text { parent }\end{array}$} & \multirow{2}{*}{$\begin{array}{l}\text { No of } \\
\text { children }\end{array}$} & \multirow{2}{*}{$\begin{array}{l}\text { Mean }(S D) \\
\text { days stay } \\
\text { with } \\
\text { parent }\end{array}$} & \multirow{2}{*}{$\begin{array}{l}\text { No of } \\
\text { children }\end{array}$} & \multirow{2}{*}{$\begin{array}{l}\text { Difference } \\
\text { (days) }\end{array}$} & \multicolumn{5}{|c|}{ Log transformation } \\
\hline & & & & & & $d f$ & $t$ & $\begin{array}{l}\text { Ratio of } \\
\text { geometric } \\
\text { means }\end{array}$ & p Value & $\begin{array}{l}95 \% \\
\text { Confidence } \\
\text { interval }\end{array}$ \\
\hline All groups & $4 \cdot 2(2 \cdot 9)$ & 450 & $2.9(2 \cdot 7)$ & 136 & $1 \cdot 3$ & 584 & $5 \cdot 42$ & $1 \cdot 51$ & $<0.001$ & 1.30 to 1.76 \\
\hline $\begin{array}{l}\text { Upper respiratory } \\
\text { tract infection group } \\
\text { Lower respiratory }\end{array}$ & $3 \cdot 6(2 \cdot 3)$ & 142 & $2 \cdot 2(2 \cdot 2)$ & 46 & $1 \cdot 4$ & 186 & $4 \cdot 69$ & 1.72 & $<0.001$ & $1 \cdot 37$ to $2 \cdot 16$ \\
\hline $\begin{array}{l}\text { tract infection group } \\
\text { Upper respiratory }\end{array}$ & $5 \cdot 3(2 \cdot 9)$ & 121 & $3.6(3.4)$ & 32 & $1 \cdot 7$ & 151 & $4 \cdot 03$ & $1 \cdot 8$ & $<0.001$ & $1 \cdot 35$ to 2.40 \\
\hline tract infection & $3 \cdot 8(2 \cdot 3)$ & 112 & $2.4(2.4)$ & 35 & $1 \cdot 4$ & 145 & 4.09 & 1.67 & $<0.001$ & $1 \cdot 31$ to $2 \cdot 17$ \\
\hline Herpes stomatitis & $5.7(3.0)$ & 9 & $1.8(1.0)$ & 4 & 3.9 & 11 & 4.01 & $3 \cdot 26$ & $<0.005$ & 1.70 to 6.24 \\
\hline Pneumonia & $5.4(2 \cdot 7)$ & 61 & $4 \cdot 1(4 \cdot 0)$ & 18 & $1 \cdot 3$ & 77 & 3.03 & 1.73 & $<0.005$ & 1.20 to 2.47 \\
\hline Tonsilitis and croup & $3.0(2.0)$ & 23 & $1.4(0.9)$ & 7 & $1 \cdot 6$ & 28 & $2 \cdot 24$ & $2 \cdot 02$ & $<0.05$ & 1.06 to 3.86 \\
\hline Bacterial meningitis & $10 \cdot 8(1.5)$ & 8 & $8.0(1.4)$ & 2 & $2 \cdot 8$ & 8 & $2 \cdot 73$ & $1 \cdot 35$ & $<0.05$ & 1.05 to 1.72 \\
\hline Bronchiolitis & $5.9(2.9)$ & 49 & $3.9(2.7)$ & 7 & $2 \cdot 0$ & 54 & $1 \cdot 78$ & & NS & \\
\hline $\begin{array}{l}\text { Unspecified viral } \\
\text { infection }\end{array}$ & $4.4(2.4)$ & 22 & $2.9(1.7)$ & 13 & 1.5 & 33 & 1.45 & & NS & \\
\hline Asthma & $3.0(2.6)$ & 103 & $2 \cdot 3(1.5)$ & 17 & 0.7 & 118 & 0.80 & & NS & \\
\hline Febrile convulsion & $3.6(2.5)$ & 34 & $2.6(2.0)$ & 17 & $1 \cdot 0$ & 49 & $1 \cdot 10$ & & NS & \\
\hline Bronchitis & $2.2(1.8)$ & 11 & $2.0(1.5)$ & 7 & $0 \cdot 2$ & 16 & 0.44 & & NS & \\
\hline Viral meningitis & $5 \cdot 1(4 \cdot 2)$ & 11 & $6.8(4.9)$ & 5 & $-1 \cdot 7$ & 14 & $-0 \cdot 76$ & & NS & \\
\hline Acute pharyngitis & $2.4(2 \cdot 2)$ & 7 & $1.5(0.6)$ & 4 & 0.9 & 9 & 0.55 & & NS & \\
\hline
\end{tabular}

Diagnoses coded according to the British Paediatric Association Classification of Diseases ${ }^{3}$ and the International Classification of Diseases ${ }^{4}$ : $047 \cdot 9+049 \cdot 0$, viral meningitis; $054 \cdot 2$, herpetic gingivostomatitis; $079 \cdot 9$, unspecified viral infection; $320 \cdot 0+320 \cdot 9$, bacterial meningitis; 462.9, acute pharyngitis*; $463.9+464 \cdot 4$, acute tonsilitis and croup*; 465.9 , upper respiratory tract infection*; $466 \cdot 0$, bronchitis $\dagger ; 466 \cdot 1$, bronchiolitis $\dagger, 485+486$, bronchopneumonia and pneumonia $\dagger$; 493.99 , asthma; $780 \cdot 30$, febrile convulsion. ${ }^{*}$ Upper respiratory tract infection group; †lower respiratory tract infection group.

Table 2 Mean duration of stay for patients with and without a resident parent in each eligibility and age group

\begin{tabular}{|c|c|c|c|c|c|c|c|}
\hline & \multirow{2}{*}{$\begin{array}{l}\text { No (\%) } \\
\text { with } \\
\text { resident } \\
\text { parent }\end{array}$} & \multicolumn{2}{|c|}{ Mean (SD) days stay } & \multirow{2}{*}{$\begin{array}{l}\text { Difference } \\
\text { (days) }\end{array}$} & \multirow{2}{*}{$\begin{array}{l}\text { Ratio of } \\
\text { geometric } \\
\text { means }\end{array}$} & \multirow{2}{*}{$\begin{array}{l}95 \% \\
\text { Confidence } \\
\text { interval for } \\
\text { ratio }\end{array}$} & \multirow[t]{2}{*}{ p Value } \\
\hline & & $\begin{array}{l}\text { Without } \\
\text { parent }\end{array}$ & $\begin{array}{l}\text { With } \\
\text { parent }\end{array}$ & & & & \\
\hline \multicolumn{8}{|l|}{ Eligibility group: } \\
\hline Group $1(n=85)$ & $11(13)$ & $4 \cdot 5(3 \cdot 1)$ & $3.5(1 \cdot 8)$ & $1 \cdot 0$ & $1 \cdot 13$ & 0.69 to 1.82 & NS \\
\hline Group $2(n=332)$ & 63 (19) & $4.3(2.8)$ & $3.0(2 \cdot 8)$ & $1 \cdot 3$ & 1.59 & 1.29 to 1.96 & $<0.001$ \\
\hline Group $3(n=169)$ & $61(36)$ & $3.7(2.9)$ & $2 \cdot 7(2 \cdot 8)$ & $1 \cdot 0$ & $1 \cdot 35$ & 1.04 to 1.75 & $<0.025$ \\
\hline \multicolumn{8}{|l|}{ Age group (years): } \\
\hline $0-1 \quad(n=156)$ & $33(21)$ & $5 \cdot 2(3 \cdot 1)$ & $3.8(3.0)$ & $1 \cdot 4$ & $1 \cdot 41$ & 1.07 to 1.87 & $<0.02$ \\
\hline$>1-3 \quad(n=184)$ & $55(30)$ & $4.0(2 \cdot 7)$ & $3 \cdot 0(3 \cdot 1)$ & $1 \cdot 0$ & 1.49 & 1.18 to 1.89 & $<0.005$ \\
\hline$>3-5 \quad(n=84)$ & $34(40)$ & $3.9(3.1)$ & $2 \cdot 1(1 \cdot 5)$ & $1 \cdot 8$ & 1.66 & $1 \cdot 17$ to $2 \cdot 35$ & $<0.005$ \\
\hline$>5-15(n=162)$ & $14(9)$ & $3.6(2.6)$ & $2 \cdot 0(1 \cdot 2)$ & $1 \cdot 6$ & $1 \cdot 67$ & 1.07 to 2.61 & $<0.025$ \\
\hline All ages $(n=586)$ & $136(23)$ & $4 \cdot 2(2 \cdot 9)$ & $2.9(2 \cdot 7)$ & $1 \cdot 3$ & $1 \cdot 51$ & 1.30 to 1.76 & $<0.001$ \\
\hline
\end{tabular}


confidence interval 0.03 to 0.26 ) and older children $\left(\chi^{2} 33 \cdot 7, \mathrm{df}=1, \mathrm{p}<0 \cdot 001, \mathrm{diff}=0 \cdot 32,95 \%\right.$ confidence interval 0.2 to 0.43 ). In all age groups the accompanied children had a shorter mean stay than the unaccompanied ones (table 2).

\section{Discussion}

Residential accommodation was available to all parents. The age distribution of the accompanied patients agrees well with the general concept that younger children, especially those of toddler age, benefit most from the emotional support of a resident parent. It is surprising that less than $30 \%$ of those under 3 years had a resident parent. An important factor may be that there were significantly more children from eligibility groups 1 and 2 in the under 3 year old group than in the older age groups $\left(\chi^{2}=6.73, d f=2, p<0.05\right)$. Almost all of the resident parents were mothers. A major factor in determining whether or not a mother lives in is the number and age of her other children. This is probably a factor influencing the high proportion of resident parents in group 3, as this group tends to have smaller families and may be able to employ help to look after any other children. These parents are also likely to be better informed and so more aware of the emotional benefit to the child of a resident parent. The asthmatic patients had the lowest percentage of resident parents. A total of $80(67 \%)$ of these children were over 5 years old and only three $(4 \%)$ of them had resident parents. Eight $(42 \%)$ of the $>1$ to 3 year group were accompanied by a resident parent, which is above the average for all diagnoses (table 2). The figure for the $>3$ to 5 year group was six (30\%); below the average for all diagnoses. Asthmatic children are likely to have attended hospital before ${ }^{5}$ and so their parents may consider they require less parental support, especially when admitted on a second or subsequent occasion.

Provision of accommodation for parents to live and sleep in hospital not only benefits the emotional well being of the child but by shortening the patients' hospital stay, increases the hospital's efficiency. Resident parents reduce the workload of hospital staff in some ways but increase it in others. Nurses and doctors spend more time explaining procedures and investigations and answering parents questions. Cleaning, catering, and laundry are all increased. Nurses have to provide far less 'mothercraft care'. Telephone enquiries are much reduced because presumably the parent keeps the family and friends informed. The play therapist's work is reduced for these children as she is able to give guidance to resident parents about facilities and equipment and leave them to play with the children. Over the last five years the number of admissions to this hospital and the proportion of resident parents have both risen, while the number of hospital staff, especially nursing staff, has fallen. Without resident parents an increase in nursing staff would be required to cater for the same number of patients, with a consequent increase in cost. For economic and emotional reasons accommodation for parents should be regarded as an important part of a unit admitting children.

We thank Miss A Gillick, the staff of the medical records departments of the National Children's Hospital and the Federated Dublin Voluntary Hospitals and Dr M O'Regan of the statistics and operations research laboratory (Trinity College, Dublin) for their help.

\section{References}

1 Platt $\mathrm{H}$, chairman. The welfare of children in hospital. London: HMSO, 1959. (Platt report.)

2 Consumers Association. Children in hospital. London: Consumers Association, 1980.

3 British Paediatric Association. British Paediatric Association classification of diseases. London: British Paediatric Association, 1979.

${ }^{4}$ World Health Organisation. International classification of diseases. Geneva: World Health Organisation, 1977.

5 Carson JWK, Taylor MRH, Cagney B. Underutilisation of prophylactic drugs in asthmatic children. Ir Med J 1985;78: 38-40.

Correspondence to Dr MRH Taylor, National Children's Hospital, Harcourt Street, Dublin 2.

Accepted 18 July 1988 